\title{
Correction to: Marshall Sklare Award Lecture, 2016: Beyond Policy: New Directions for Jewish Demography
}

\author{
Bruce A. Phillips ${ }^{1}$
}

Published online: 9 November 2017

(C) Springer Science+Business Media B.V., part of Springer Nature 2017

\section{Correction to: Cont Jewry https://doi.org/10.1007/s12397-017-9241-6}

Unfortunately, in the original publication of the article, the year of 2017 in the article title for the Sklare Memorial Award Lecture is incorrect. The correct title is "Marshall Sklare Award Lecture, 2016: Beyond Policy: New Directions for Jewish Demography."

The original article can be found online at https://doi.org/10.1007/s12397-017-9241-6.

Bruce A. Phillips

baphucusc@gmail.com

1 Los Angeles, CA, USA 